\title{
Identification of glycoproteins in mucous cells of the gill epithelium of Colossoma macropomum after exposure to organophosphate
}

\author{
[Identificação das glicoproteínas nas células mucosas do epitélio branquial de Colossoma macropomum \\ após exposição ao organofosforado] \\ S.E. Moron ${ }^{1}$, P.R. Matos ${ }^{1}$, A.T. Ramos ${ }^{2}$, M.G.T. Gomes ${ }^{1}$ \\ ${ }^{1}$ Universidade Federal do Tocantins - Araguaína, TO \\ ${ }^{2}$ Universidade Federal de Santa Catarina - Florianópolis, SC
}

\begin{abstract}
The use of organophosphates has been recommended for fish, especially the trichlorfon to control parasites. Colossoma macropomum were exposed to trichlorfon during 96 hours and of total number of mucous cells decreased in the number of cells when compared to the control group. Glycoproteins acid, acid sulphated and neutral was identified in the gill epithelium. Neutra glycoprotein had a significant decrease between control and the sublethal concentration. Acid glycoprotein didn't have any significant difference between the groups exposed to the trichlorfon, compared to the control group. Sulfated acidic glycoprotein in the group exposed to the trichlorfon was noticed a reduction in number of mucosal cells acidic sulphated. The differences between density cell and production glycoprotein was a response of these cells after exposure to xenobiotic. The reduction of neutral, acid and sulphated acid glycoprotein in the MC of the gill epithelium Colossoma macropomum may affect gills epithelial surface protection by reducing the formation of an unstirred layer and enhance the ion loss.
\end{abstract}

Keywords: epithelium, glycoproteins, organophosphate, trichlorfon

\section{RESUMO}

A utilização de organofosforados tem sido recomendada em pisciculturas, principalmente o trichlorfon, para o controle de parasitoses. Colossoma macropomum foram expostos ao trichlorfon durante 96 horas, e o número total de células mucosas diminuiu no número de células quando comparado com o grupo controle. Glicoproteínas ácida, ácida sulfatada e neutra foram identificadas no epitélio branquial. Glicoproteína neutra teve uma diminuição significativa entre o controle e a concentração subletal. Glicoproteína ácida não apresentou diferença significativa entre os grupos expostos ao triclorfon, em comparação com o grupo controle. Glicoproteína ácida sulfatada no grupo exposto ao triclorfon teve uma redução no número de células da mucosa ácida sulfatada. As diferenças entre a densidade celular e a produção de glicoproteína foi uma resposta dessas células após exposição aos xenobióticos. A redução das glicoproteínas neutra, ácida e ácida sulfatada no epitélio branquial de Colossoma macropomum pode afetar a proteção da superfície, reduzindo a formação de uma camada de muco, e aumentar a perda de íons.

Palavras-chave: epitélio, glicoproteínas, organofosforado, trichlorfon

\section{INTRODUCTION}

In the fish, the mucous cells are unique in their histological characteristics as size, numbers and studies have been carried out on the fish skin's mucous cells (Diaz et al., 2005).

Recebido em 18 de abril de 2016

Aceito em 11 de setembro de 2017

E-mail: sandromoron@uft.edu.br
The mucus, secreted by the mucous cells, on the gills surface has been considered an important protection against abrasive injuries by solid materials suspended in water, pathogenic bacteria, parasites (McCahon et al., 1987; Deszfuli et al., 2003), and pollutant (Ledy et al., 2003; Roberts and Powell, 2003). Furthermore, mucus may play a role in the ion regulation 
(Handy et al., 1989; Roberts and Powell, 2003; Powel, 2007).

Mucous cells present in the gills filaments epithelium and their secretion may be a mechanism for adaptation to different conditions of the aquatic environment. Changes in the density of the gills' mucous cells have been considered as a response to the changes in the ion concentration in water such as sodium, calcium and chloride (Perry and Wood, 1985; Laurent and Hebibi, 1989; Moron et al., 2009) and xenobiotics (Wendelaar Bonga et al., 1989).

In aquaculture, the organophosphate insecticides are used in the control of odonata, an insect which is the main predator of fish (Mataqueiro, 2002) and used in the treatment and in the control of other predators (Carr and Chambers, 1996). In fish farming they tend to eliminate and control ectoparasites (Rodrigues et al., 1997). Products that contain Trichlorfon [dimethyl, (2,2,2-trichloro-1-hydroxyethyl phosphonate)] are selective organophosphate compounds, since active principles are repeatedly and recklessly used in Brazilian fish cultures in high concentrations and without specialized technical orientation (Guimarães and Calil, 2008). The effects caused by the exposure to organophosphates have been broadly studied (Pope, 1999; Fulton and Key, 2001; Fanta et al., 2003; Roex et al. 2003; Aguiar et al., 2004; Mohammad et al., 2004; Chandrasekara and Pathiratne, 2005; Thomaz et. al., 2009).

The objective of this study was to compare the responses of Colossoma macropomum's mucous cells in gills after exposed organophosphate insecticides.

\section{MATERIAL AND METHODS}

In Laboratory for adaptation of fish with environmental conditions, fish stocked in a polyethylene box of 500 liters under natural photoperiod $(\sim 12: 12 \mathrm{~h})$ and continuous supply of aeration with air pumps. During this period, fish were fed ad libitum with commercial fish pellets and stopped 12 hours before the experiment. After acclimatization, the fish $(150.0 \pm 10 \mathrm{~g})$ were divided into two groups of 10 individuals each and each group: control group and test groupanimals treated with pesticide NEGUVON $^{\circledR}$ (active principle is trichlorfon $97 \mathrm{~g} / 100 \mathrm{~g}$ ) $0,25 \mathrm{mg}$
$\mathrm{L}^{-1}$ in a semi-static system (period of 96 hours). Three replicates per groups were used to provide a stronger statistical baseline. The analyzed materials were collected after the exposure periods. Before sacrifice, which was accomplished to collect the organs, the animals were anesthetized with benzocaine solution. The gills of each group were fixed in aqueous Bouin. Gill filament samples were dehydrated in ethanol crescent series until pure ethanol, embedded in paraffin and serially sectioned at $3 \mu \mathrm{m}$ for light microscopy (LM). Toluidine blue was used to count total number of mucous cells. Mucins were demonstrated using Alcian blue (AB) at $\mathrm{pH}$ 1. 0 (sulphated acid glycoprotein, Lev and Spicer, 1964) and $\mathrm{pH} 2.5$ (acid glycoprotein, Mowry, 1956) and, periodic acid-Schiff (neutral glycoprotein, McManaus, 1948). In addition, the PAS technique was employed in combination with $\mathrm{AB} \mathrm{pH} 1.0$ and $\mathrm{pH} 2.5$ to the identification of $\mathrm{MC}$ containing more than one type of glycoprotein. Methylation and saponification processes were used to prove the chemical nature of the mucosubstances. The quantification of MCs and the identification of the glycoprotein were based on the intensity of histochemistry reactions against a background stain, when necessary, for better visualization of the gill epithelium. Stained sections were examined under a light microscope Leica using systematic 10 random fields in each section. Positivestaining MCs were assessed semi quantitatively as 0 unstained, + weak, ++ moderated, +++ strong. The identification of mucous cells present in branchial arches was "fields" in random filaments.

The statistical analyses were done using the program GraphPad Instat (GraphPad Software, version 3.0, San Diego, CA). Comparisons between the media obtained were for Student's T Test with $95 \%$ confidence interval. The protocol for this experiment was reviewed and approved by the Ethics Committee on Animal Use (23101.002494/2014-38), Federal University of Tocantins.

\section{RESULTS AND DISCUSSION}

Three glycoproteins types (acid, acid sulphated and neutral) were identified in the gill epithelium (Table 1). Histochemical differences in the mucin contents of branchial mucous cells among several species of fish were reported (Zaccone, 
1972; Yamada and Yokote, 1975; Fletcher et al., 1976; Gona, 1979).

Table 1. Mucosubstances in the mucous cells of the gill epithelium of Colossoma macropomum of the controls groups and groups maintained in trichlorfon $\left(0,25 \mathrm{mg} \mathrm{L}^{-1}\right)$

\begin{tabular}{lcc}
\hline \multicolumn{3}{c}{ Mucosubstances in the mucous cells } \\
\hline Glycoproteins & Control & Trichlorfon \\
Neutral & +++ & + \\
Acid & ++ & ++ \\
Sulphated acid & ++ & + \\
\hline $0=$ negative reaction; $+=$ weak positive reaction; ++ \\
$=$ moderate positive reaction; $+++=$ intense positive \\
reaction.
\end{tabular}

In the results of measurements, total number of mucous cells a decrease in the cells' number was observed in Trichlorfon concentration when compared to the control group (Figure 1 and 2).

Neutra glycoprotein showed a significant decrease between control and sublethal concentration (Figure 3). Acid glycoprotein didn't have any significant difference between the groups exposed to the Trichlorfon, compared to the control group (Figure 4). Sulfated acidic glycoprotein in the group exposed to the Trichlorfon showed a reduction in number of mucosal cells acidic sulphated (Figure 5).

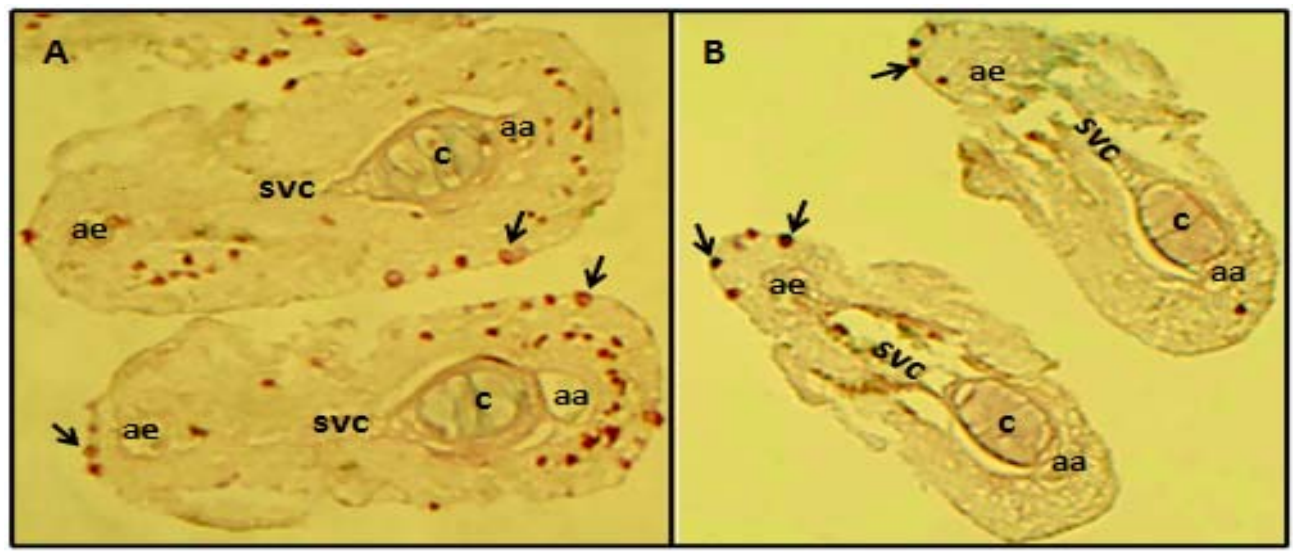

Figure 1. Cross section of filament showing the distribution of mucous cells (arrowheads). A (control) and B (Trichlorfon concentration), aa - filament afferent artery, c - cartilage, svc - central venous sinus, ae - filament efferent artery. Stained: Reagent and Periodic Acid Shiff (PAS). Magnification: 10x.

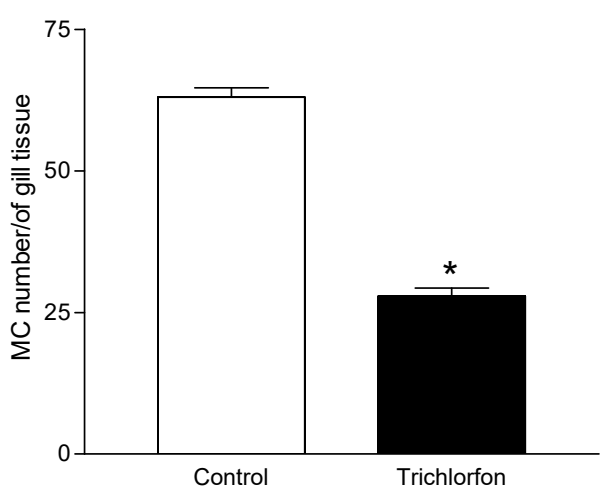

Figure 2. Number of mucous cell in the epithelium gill in the concentration of $0,25 \mathrm{mg} \mathrm{L}^{-1}$ trichlorfon. Total number of mucous cells a decrease in the cells' number was observed in Trichlorfon concentration when compared to the control group. $(*)$ significant difference.

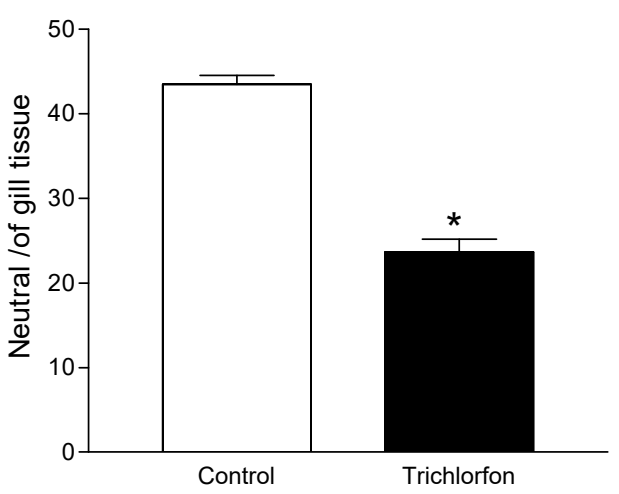

Figure 3. Means values of the cell density (neutral glycoprotein) filament gill in the concentration of $0,25 \mathrm{mg}$ $\mathrm{L}^{-1}$ trichlorfon. Neutra glycoprotein showed a significant decrease between control and sublethal concentration. $\left({ }^{*}\right)$ significant difference. 


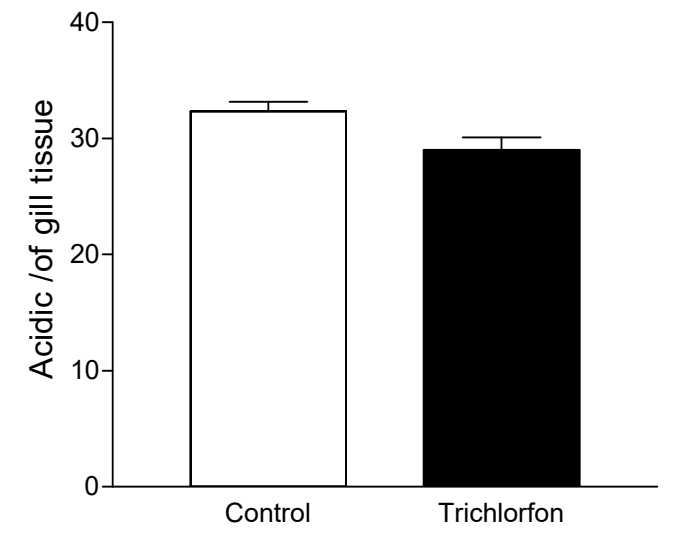

Figure 4. Means values of the cell density (acidic glycoprotein) filament gill in the concentration of $0,25 \mathrm{mg} \mathrm{L}^{-1}$ trichlorfon. Acid glycoprotein didn't have any significant difference between the groups exposed to the Trichlorfon.

The MC density and mucus production diverge among different fish species as well as the response of these cells to environmental conditions (Laurent, 1984). Handy and Eddy (1991) demonstrated the absence of mucus in the surface of the gills of Oncorhynchus mykiss. Numerous studies showed that high amounts of mucus secretion are induced by acid stress (Berntssen et al., 1997), air exposure (Olson, 1996), gills diseases (Powel, 2007), salinity (Roberts and Powell, 2003), and pollutants (Fernandes and Mazon, 2003).

The histochemical procedures for visualizing and identifying glycoconjugates in the mucous cells of primary as well as secondary lamellae (Diaz et al., 2005). Several MC types have been described in the teleost epidermis and gills based on the distribution and mucus histochemistry (Mittal et al., 1994). The main components of mucus are high molecular weight glycoproteins with numerous carbohydrate chains linked to a protein core (Buekhardt-Holm, 1997).

Neutral glycoprotein has low viscosity and may protect and lubricate gill epithelium against the physical injuries while the acid and sulphated acid glycoproteins demonstrated high viscosity and may help the adhesion of particles in suspension in water (Sibbing and Uribe, 1985) or prevent the proliferation of potentially pathogenic microorganisms in the epithelial surface (Mittal et al., 1994).

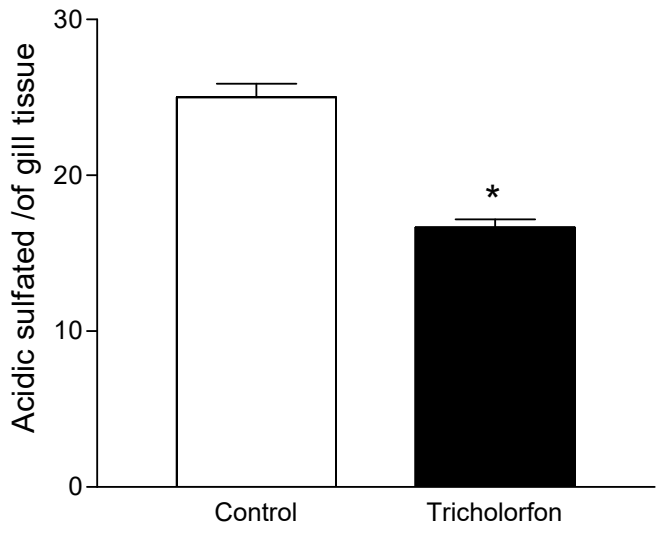

Figure 5. Means values of the cell density (acidic sulfated glycoprotein) filament gill in the concentration of $0,25 \mathrm{mg}$ $\mathrm{L}^{-1}$ trichlorfon. Sulfated acidic glycoprotein in the group exposed to the Trichlorfon showed a significant reduction. $(*)$ significant difference.

The differences in cell density and production of glycoprotein was response of these cells after exposure to xenobiotic. The reduction of neutral, acid, and sulphated acid glycoprotein in the MC of the gill epithelium Colossoma macropomum may affect the surface protection by reducing the formation of an unstirred layer and enhance the ion loss.

Breseghelo et al. (2004) found a higher intensity of neutral glycoconjugates in the control group fish guppy (Poecilia vivipara) on the effect of sodium fluoride and higher intensity of glycoconjugates carboxylated acids in the experimental group. Sadauskas-Henrique (2008) observed decrease in mucous cells containing sulfated and acidic glycoprotein in Astyanax fasciatus, according to the author that reaction may have been due to the presence of organochlorine pesticides in the water, but a contrary response was observed in the species Pimelodua maculatus, which showed an increase of mucous cells with sulphated glycoprotein and acidic. Berntssen et al. (1997) observed a decrease in number of skin mucous cells and increase in the skin acidic mucosubstances after aluminium exposure at low $\mathrm{pH}$ in Atlantic salmon.

The reduction of glycoproteins in the gill epithelium may be considered as a disadvantage for this species after exposure to xenobiotic, as 
the reduction of unstirred mucus layer may reduce the ion gradient close to epithelial surface and favor ion loss. However, the functional consequence of this depends on the ability of ion-exchange membrane to restrict electrolyte diffusion.

\section{CONCLUSION}

The total number of mucous cells decreases in Trichlorfon sublethal concentration. The differences between cell density and production of glycoprotein is a response after exposure to xenobiotic, and may be considered a disadvantage for this species. The decreasing of such mucosubstances also reduces the mucus protection in gill tissue.

\section{ACKNOWLEDGEMENTS}

To Conselho Nacional de Desenvolvimento Científico e Tecnológico (CNPq) for financial support.

\section{REFERENCES}

AGUIAR, L.H.; MORAES, G.; AVILEZ, I.M. et al. Metabolical effects of Folidol 600 on the neotropical freshwater fish matrinxa, Brycon cephalus. Environ. Res., v.95, p.224-230, 2004.

BERNTSSEN, M.H.G.; KROGLUND, F.; ROSSELAND, B.O. et al. Responses of skin mucous cells to aluminium exposure at low $\mathrm{pH}$ in Atlantic salmon (Salmo salar) smolts. Can. J. Fish. Aquat. Sci., v.54, p.1039-1045, 1997.

BRESEGHELO, L.; CARDOSO, M.B.; COSTA, M.F. et al. Effects of sodium fluoride in the fish's gill epithelium guaru (Poecilia vivipara). Braz. J. Vet. Res. Anim. Sci., v.41, p.274-280, 2004.

BUEKHARDT-HOLM, P. Lectin histochemistry of rainbow trout (OncorHychus mykiss) gill and skin. Histoch. J., v.29, p.893-899, 1997.

CARR, L.R.; CHAMBERS, J.E. Kinetic analysis of in vitro inhibition, aging, and reactivation of brain acetylcholinesterase from rat and channel catfish by paraoxon and chloropyrifos-oxon. Toxicol. Appl. Pharmacol., v.139, p.365-373, 1996.

CHANDRASEKARA， H.U.; PATHIRATNE， A. Acetylcholinesterase inhibition and haematological alterations induced in common carp, (Cyprinus carpio) following exposure to low concentrations of Trichlorfon. J. Aquac. Res., v.36, p.146-150, 2005.
DEZFULI, B.S.; GIARI, L.; KONECNY, R. et al. Immunohistochermistry, ultrastructure and pathology of gills of Abramis brama from Lake Mondsee, Austria, infected with Ergasilus sieboldi (Copepoda). Dis. Aquat. Org., v.53, p.257-262, 2003.

DIAZ, A.O.; GARCIA, A.M.; DEVINCENTI, C.V.; GOLDEMBERG, A.L. Ultrastructure and histochemical study of glycoconjugates in the gills of the white croaker (Micropogonias furnieri). Anat. Hist. Embryol., v.34, p.117-122, 2005.

FANTA, E.; RIOS, F.S.; ROMÃO, S. et al. Histopathogy of the fish's Corydoras paleatus contaminated with sublethal levels of organophosphorus in water and food. Ecotox. Environ. Saf., v.54, p.119-130, 2003.

FERNANDES, M.N.; MAZON, A.F. Environmental pollution and fish's gill morphology. In: VAL, A.L.; KAPOOR, B.G. (Eds.). Fish adaptation. Enf. Sci. Publish., p.418, 2003.

FLETCHER, T.C.; JONES, R.; REID, L. Identification of glycoproteins in goblet cells of epidermis and gill of plaice (Pleuronectes platessa L.), flounder (Platichthys flesus) and rainbow trout (Salmo gairdneri Richardson). Histoch. J., v.8, p.597-608, 1976.

FULTON, M.H; KEY, P.B. Acetylcholinesterase inhibition in estuarine fish and invertebrates as an indicator of organophosphorus insecticide exposure and effects. Environ. Toxicol. Chem., v.20, p.37-45, 2001.

GONA, O. Mucus glycoproteins of teleostean fish, a comparative histochemical study. Histoch. J., v.11, p.709-718, 1979.

GUIMARÃES, A.T.B.; CALIL, P. Growth evaluation of oreochromis niloticus (Cichlidae, Neopterygii) exposed to trichlorfon. Braz. Arch. Biol. Technol., v.51, p.323-332, 2008.

HANDY, R.D.; EDDY, F.B.; ROMAIN, G. In vitro evidence for the ionoregulatory role of rainbow trout mucus in acid, acid/aluminum and zinc toxicity. $J$. Fish Biol., v.35, p.737-747, 1989.

HANDY, R.D.; EDDY, F.B. The absence of mucus on the secondary lamellae of unstressed rainbow trout, Oncorhynchus mykiss (Walbaum). J. Fish Biol., v.38, p.153-155, 1991.

LAURENT, P. Internal morphology of the gill. In: HOAR, W.S.; RANDALL, D.J.; (Eds.). Fish physiology. Orlando: Academic Press, 1984. v.10, $454 \mathrm{p}$.

LAURENT, P.; HEBIBI, N. Gill morphometry and fish osmoregulation. Can. J. Zool., v.67, p.3055-3063, 1989. 
LEDY, K.; GIAMBERINI, L.; PIHAN, J.C. Mucous cell responses in gill and skin of brown trout Salmotruttafarioin acidic, aluminium-containing stream water. Dis. Aquat. Org., v.56, p.235-240, 2003.

LEV, R.; SPICER, S.S. Specific staining of sulphate groups with alcian blue at low pH. J. Histoch. Cytoch., v.2, p.309-309, 1964.

MATAQUEIRO, M.I. Acute and subacute toxicity of insecticide methyl paration in pacu (Piaractus mesopotamicus, Holmberg, 1887). 2002. 41f. Dissertation (Master's Degree in Aquaculture from Continental Waters) - Aquaculture Centre of Universidade Estadual Paulista, Jaboticabal, SP.

MCCAHON, C.P.; PASCOE, D.; KAVANAGH, M. Histochemical observations on the salmonids Salmo salar L. and Salmo trutta L. and the ephemeropterans Baetis rhodani (Pict.) and Ecdyonurus venosus (Fabr.) following a simulated episode of acidity in an upland stream. Hydrobiologia, v.153, p.3-12, 1987.

MCMANUS, J.F.A. Histological and histochemical uses of periodic acid. Stain Technol., v.23, p.99-108, 1948.

MITTAL, A.K.; UEDA, T.; FUJIMORI, O.; YAMADA, K. Histochermical analysis of glycoproteins in the unicellular glands in the epidermis of an Indian freshwater fish Mastacembeluspancalus (Hamilton). Histoch. J., v.26, p.666-677, 1994.

MOHAMMAD, A.; RANJBAR, A.; SHAHIN, S. et al. Pesticides and oxidative stress: a review. Med. Sci. Monit., v.10, p.141-147, 2004.

MORON, S.E.; ANDRADE, A.C.; FERNANDES, M.N. Response of traíra's mucous' gill (Hoplias malabaricus) and jeju (Hoplerythrinus unitaeniatus) (Teleostei: Erythrinidae) to hypo- and hyper-osmotic ion stress. Neotrop. Ichthyol., v.7, p.491-498, 2009.

MOWRY, R.W. Alcian blue techniques for the histochemical study of acidic carbohydrates. $J$. Histoch. Cytoch., v.4, p.407-408, 1956.

OLSON, K.R. Scanning electron microscopy of the fish's gill. In: MUNSHI, J.S.D.; DUTTA, H.M. (Eds.). Fish morphology. [s.1.]: Brookfield, CRC Press, 1996. p.31-45.

PERRY, S.F.; WOOD, C.M. Kinetics of brachial calcium uptake in the rainbow trout: effects of acclimation to various external calcium levels. $J$. Experim. Biol., v.116, p.411-433, 1985.

POPE, C.N. Organophosphorus pesticides: do they all have the same mechanism of toxicity? J. Toxicol. Environ. Health, v.2, p.161-181, 1999.
POWEL, M.D. Respiration in infectious and noninfectious gill diseases. In: FERNANDES, M.N.; GLASS, M.L.; RANTIN, F.T.; KAPOOR, B.G. (Eds.). Fish respiration and environment. Enfield: Science Publisher, 2007. 392p.

ROBERTS, S.D.; POWELL, M.D. Comparative ionic flux and gill's mucous cell histochemistry: effects of salinity and disease status in Atlantic salmon (Salmo salar L.). Comp. Bioch. Physiol. A, v.134, p.525-537, 2003.

RODRIGUES, E.L.; RANZANI-PAIVA, M.J.; PACHECO, F.J. et al. Acute effect of Dipterex organophosphate (Trichlorfon) 500 in spleen decurimbatá Prochilodus scrofa (STEINDACHNER, 1881). Bull. Fish. Inst., v.24, p.197-203,1997.

ROEX, E.W.; KEIJZER, R.; VAN GESTEL, C.A. Acetylcholinesterase inhibition and increased food consumption rate in the zebrafish, Danio rerio, after chronic exposure to parathion. Aquat. Toxicol., v.64, p.451-460, 2003.

SADAUSKAS-HENRIQUE, H. Fisioecológicos aspects of Astyanax fasciatus and Pimelodus maculatus (teleosts) of the Reservoir of the Hydroelectric Plant of Furnas, MG: functional assessment of gills and Hematological variables. 2008. 134f. Dissertation (Master's) - Federal University of São Carlos, São Carlos, S.P.

SIBBING, F.A.; URIBE, R. Regional specialization in the oropharyngealwall and food processing in the carpa (Cyprinus carpio). Netherl. J. Zool., v.35, p.377422,1985

THOMAZ, J.M.; MARTINS, N.D.M.; MONTEIRO, D.M. et al. Cardio-respiratory function and oxidative stress biomarkers in Nile tilapia exposed to the organophosphate insecticide trichlorfon (NEGUVON). Ecotox. Environ. Saf., v.72, p.1413-1424, 2009.

WENDELAAR-BONGA, S.E.; VAN DER MEIJ, C.J.M. Degeneration and death, by apoptosis and necrosis the pavement and cells the gills of the teleost Oreochromis mossambicus. Cell Tissue Res., v.255, p.235-243, 1989.

YAMADA, K.; YOKOTE, M. Morphochemical analysis of mucosubstances in some epithelial tissues of eel (Anguill japonica). Histochemistry, v.43, p.161172,1975

ZACCONE, G. Comparative histochemical investigations on the mucous cells of the branchial epithelium of Mugil cephalus L. and Anoptichthys jordani Hubbs and Innes. Acta Histochem., v.44, p.106-115, 1972. 